\title{
Review article: \\ THE EFFECT OF EXERCISE ON FAT BROWNING THROUGH PLASMA IRISIN LEVEL MODULATION TO OVERCOME OBESITY
}

\author{
Miftahul Nur Amaliyah, Purwo Sri Rejeki \\ Department of Physiology, Sport Health Science Program Faculty of Medicine, Universitas Airlangga, Surabaya, \\ Indonesia
}

\section{ABSTRACT}

\begin{abstract}
Overweight and obesity incidence continues to increase and becomes a global problem in recent decades. One of the pathophysiology is a low energy output, therefore energy homeostasis shifts positively. Exercise is considered as an effective method to increase energy output. Irisin is one of myokine type that is secreted to the bloodstream while exercising and causes changes in subcutaneous adipose tissue. In adipose cells, irisin will stimulate the browning process in White Adipose Tissue to increase thermogenesis and lipolysis.
\end{abstract}

Keywords: Sport; irisin; fat browning; obesity

\section{ABSTRAK}

Kejadian kelebihan berat badan dan obesitas terus meningkat dan menjadi masalah global dalam beberapa dekade terakhir. Salah satu patofisiologi adalah output energi yang rendah, sehingga homeostasis energi bergeser positif. Latihan dianggap sebagai metode yang efektif untuk meningkatkan output energi. Irisin adalah salah satu tipe myokine yang disekresikan ke aliran darah saat berolahraga dan menyebabkan perubahan pada jaringan adiposa subkutan. Dalam sel adiposa, irisin akan menstimulasi proses pencoklatan pada Jaringan Adiposa Putih untuk meningkatkan termogenesis dan lipolisis.

Kata kunci: gangguan bipolar; valproatee; fluoxetine; YMRS; MADRS

Correspondence: Purwo Sri Rejeki, Department of Physiology, Sport Health Science Program Faculty of Medicine, Universitas Airlangga, Surabaya, Indonesia. E-mail: purwo_faal@yahoo.com

pISSN:2355-8393 • eISSN: 2599-056x • doi: http://dx.doi.org/10.20473/fmi.v54i4.10718

- Fol Med Indones. 2018;54:301-305 • Received 15 Oct 2018 • Accepted 20 Nov 2018

- Open access under CC-BY-NC-SA license • Available at https://e-journal.unair.ac.id/FMI/

\section{INTRODUCTION}

The incidence of overweight and obesity continues to increase and has become a global problem in recent decades (Rejeki et al 2016, Sanchez-Delgado et al 2015). World Health Organization shows that in 2014, $39 \%$ of the world's population above 18 years old experienced overweight, while $13 \%$ experienced obesity. According to the 2013 Basic Health Research, in Indonesia, the obesity prevalence of adult males $(>18$ years) was $19.7 \%$, higher than in $2007(13.9 \%)$ and in 2010 (7.8\%). Whereas, the obesity prevalence of adult female population was 32.9\%, increasing from 2007 $(18.1 \%)$ and in $2010(15.5 \%)$. In 2010, obesity is estimated to cause 3.4 million deaths worldwide. Overweight and obesity are related to an increased risk of insulin resistance, metabolic syndrome, cardiovascular disease, and type 2 diabetes (Afshin et al 2017).
Various risk factors have a relationship with overweight and obesity in Indonesia including gender (Rejeki et al 2017) and physical activity. Women have a risk of overweight and obesity at 1.76 times and 3.43 times compared to men respectively. Those who have less physical activity also have a risk of overweight (1.7 times) and obesity (2.55 times) compared to those with sufficient physical activity (Sudikno et al 2015). Shifting the balance of energy in a positive direction will save excess energy in adipocytes of adipose tissue.

Adipose tissue can be divided into two, White Adipose Tissue (WAT) and Brown Adipose Tissue (BAT). Both types have an opposite role in energy metabolism. WAT has the ability to store energy in the form of triglycerides and releases energy in the form of free fatty acids and glycerol, while BAT releases energy in 
the form of heat by oxidizing glucose and lipids (Cannon \& Nedergaard 2004).

Many therapeutic modalities can be used to lose weight, including increasing physical activity, exercising, and increasing active life habits (Robert 2009). Exercise is considered as an effective method in preventing obesity (Huh et al 2014). In 2012, Boström has found a myokine known as irisin which elevated while exercising and caused changes in subcutaneous fat tissue in experimental animals thereby improving weight regulation and glucose homeostasis (Bostrom et al 2012).

\section{Obesity}

Overweight and obesity are conditions in which there is accumulation of fat that can affect individual health. Body Mass Index (BMI) is a simple index used to classify body mass categories in adults with kilograms per square meter $(\mathrm{kg} / \mathrm{m} 2)$. The following classification is according to WHO and Asia-Pacific (WHO 2016).

Table 1. WHO and Asia-Pasific BMI Classifications

\begin{tabular}{lcc}
\hline \multirow{2}{*}{ Classifications } & \multicolumn{2}{c}{ BMI } \\
\cline { 2 - 3 } & WHO & Asia-Pasific \\
\hline Underweight & $<18.5$ & $<18.5$ \\
Normal & $18.5-24.9$ & $18.5-22.9$ \\
Overweight & $25-29.9$ & $23-24.9$ \\
Obese & $\geq 30$ & $\geq 25$ \\
\hline
\end{tabular}

It is seen that both WHO and Asia-Pacific use 4 classifications, namely underweight, normal, overweight, and obese with their own limit values. From the table we can conclude that Asia-Pacific classification tends to have lower limit values than WHO.

The increase in the incidence of overweight and obesity is caused by several factors, including: (1) the energy entry that exceeds energy expenditure, then most of the excess energy will be stored as fat, (2) irregular eating arrangements, (3) inactive lifestyle, (4) environmental, social, and psychological factors causing abnormal eating behavior, (5) excessive nutrition in childhood, and (6) neurogenic disorders and genetic factors (Guyton \& Hall 2014).

Overweight and obesity are associated with various chronic diseases including heart disease, Diabetes Mellitus, cancer, and various musculoskeletal problems. Figure 1 below shows that BMI and death ratio has a linear correlation. Lifestyle intervention combined with reduction in energy homeostasis by increasing energy output through exercise and other physical activities can reduce $9 \%-10 \%$ initial body weight. In order to optimize weight loss, it should be balanced with adequate food intake to meet the adequacy of energy metabolism (Linda 2014).

\section{Adipose tissue}

Adipose tissue is classified based on color differences, namely white adipose tissue (WAT), brown adipose tissue (BAT) and beige/brite/brown-like adipose tissue (bAT) (Cedikova et al 2016). WAT is divided into visceral white adipose tissue (vWAT) and subcutaneous white adipose tissue (scWAT) (Cui \& Chen 2017). WAT generally represents $20 \%$ of normal adult body weight and acts as a storage for triglycerides, from excess calories saving that will be used during starvation. WAT contributes to overall body insulation and has endocrine functions including leptin secretion, Tumor Necrotizing Factor- $\alpha$ (TNF- $\alpha$ ), adiponectin, resistin, and other compounds associated with obesity and insulin sensitivity (Cedikova et al 2016). Whereas, BAT involves in metabolism, especially during heat formation. Therefore this tissue is very active in some species that experience long-term hibernation and heat formation in newborns (thermogenesis without shivering) (Robert 2009). Recent research shows that adults also have BAT that are metabolically active and BAT plays an important role in homeostatic energy (Saely et al 2012). Furthermore, bAT has a characteristic mixture between WAT and BAT. During basal conditions, bAT shows unilocular morphology like WAT, but the appearance follows the morphological features of BAT when stimulated and eventually results in the expression of a typical protein for BAT so that fats are stored into small droplet lipids like in BAT, as we see in Fig. 2 (Cedikova et al 2016).

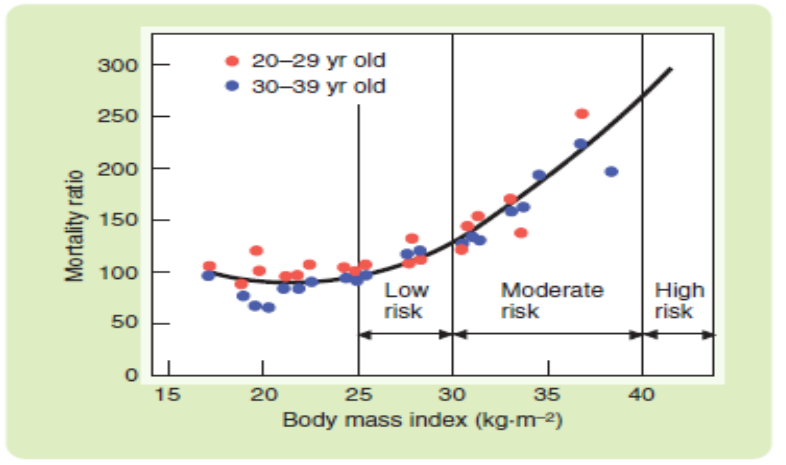

Fig. 1. Correlation between BMI and mortality ratio.

Human have a relatively large BAT deposit during infant, only a small number of BAT scattered throughout the WAT deposition survive into adulthood. The classic BAT is mainly distributed to the interscapular, paravertebral, axillary, and perirenal spaces. Recent studies have confirmed the presence of 
active BAT in adult, located in the cervical, supraclavicular, mediastinal, paravertebral, and suprarenal regions (Cedikova et al 2016).

\section{Physical exercise}

Exercise is a systematic programmed process in preparing athletes at the maximum level of performance performed repeatedly with increasing training loads (Bompa \& Haff 2009). Whereas, exercise is defined as some and all activities involving muscle activation. The term "exercise" can contain several meanings such as: practice, exercises, and training. In Indonesian these words have the same meaning, namely training, but in English each word has different meanings (Emral 2017, Foss \& Keteyjan 1998).

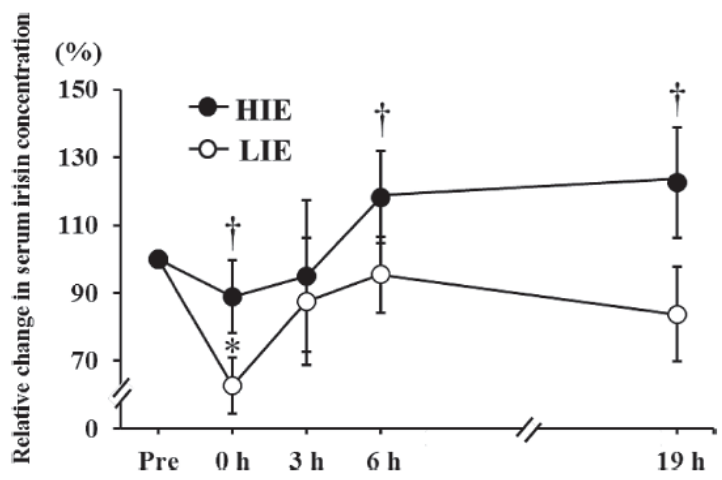

Fig. 2. Changes of Irisin Serum Concentration After HIE and LIE administered.

Practice is an activity to increase exercise skills by using equipment that suits the goals and needs. While the definition of exercise derived from the word exercises, the main tool in the daily exercise process to improve the quality of organ system. So, exercises are training materials designed and compiled by the trainer for one training session. Training is a process of improving the ability to exercise which contains theoretical and practical material, using methods and rules of implementation with a scientific approach, using the principles of planned and regular schedule (Emral 2017).

Physical exercise that is performed regularly, systematically and continuously, all included in an exercise program can significantly increase physical abilities (Astrand et al 2003). Exercise causes the process of adaptation to organs. But the body needs a certain period of time in order to adapt to the load during the training process. If the load is increased gradually, the body will adjust to these changes (Emral 2017).
Factors that need to be considered in exercise are volume, intensity, frequency, and duration. Volume is the total quantity in the exercise activity performed. Another study mention that volume is a measure that shows the strength (number) of a stimulus or load (Sukadiyanto 2005). According to ACSM (2014) the training volume consists of frequency, intensity, and time (FIT). (sumber) Based on the time, volume is classified into two types, namely: relative volume, which refers to the total amount of time from a group or team during the training phase and absolute volume which means the measure of individual work performed per unit of time (Lubis 2013).

Exercise intensity is a measure that shows the quality of a stimulus or load (Sukadiyanto 2005). Intensity is the total workload of training and can be interpreted as the level of quality by giving base, moderate and severe weight (Bompa 1994, Kent 1994). Exercise intensity can be measured by calculating the heart rate (HR), the volume of oxygen $\left(\mathrm{VO}_{2}\right)$, and metabolic equivalents (METs). Exercise intensity is usually determined by calculating the lower and upper limits of the intensity used, depend on various factors, such as age, physical fitness, physical activity, and health status (Linda 2014). The method of calculating with a maximum HR can be calculated using the MHR formula $=220-$ age (Fox 1971). Maximum HR is the amount of pulse achieved when doing maximum work (Sukadiyanto 2005). Classification of intensity of physical activity can be seen in Table 2.

Table 2. Classifications of Physical Activity Intensity (ACSM, 2014)

\begin{tabular}{lc}
\hline \multicolumn{1}{c}{ Intensity } & $\% \mathrm{HR} \max$ \\
\hline Very light & $<50$ \\
Light & $50-<64$ \\
Moderate & $64-<77$ \\
Vigorous (hard) & $77-<94$ \\
Vigorous (very hard) & $94-<100$ \\
Maximal & 100 \\
\hline
\end{tabular}

The frequency of exercise is the number of times a person exercises in a week. High and low intensity of activity affects the frequency of activity, as well as both affect the duration of activity. Determination of the frequency of exercise depends on the health status and physical fitness of the athlete to be trained (Bompa 1994). Exercise can be performed 1 to 5 times per week depends on the goals to be achieved from the training program (Fox et al 1993).

Duration is a measure the length of time of stimulation. In another word, it is the length of time in one face-toface training session (Emral 2017). Exercise duration can be understood as a span of time in minutes or hours 
of exercise every week or months during an exercise program (Bompa 1994).

\section{Effect of physical exercise intensity on irisin levels}

Exercise induces irisin through an increase in the expression of peroxisome proliferator-activated receptor act coactivator-1 $\alpha$ (PGC-1 $\alpha)$ gene, along with an increase in regulation of the expression of domainprotein type 5 III fibronectin gene (FNDC5). Furthermore, proteolytic fission of FNDC5 membrane protein in skeletal muscle and subsequent will release irisin into the bloodstream (Moreno-Navarrete et al 2013). Irisin releases fat cells in the blood circulation will stimulate the browning process in white adipose tissue and increases lipolysis resulting in a decrease fat accumulation (Perakakis et al 2017).

Improved program and regular physical training will certainly improve a person's quality of life. However, when a person has a lesser physical activity and exceed energy input than output, then most of the excess energy will be stored as fat, continuously build up fat mass which results in health problems (Guyton \& Hall 2014).

Irisin is a type of myokine found by Boström in 2012 which is secreted while exercising and causes changes in subcutaneous fat tissue in experimental animals thereby improving weight regulation and glucose homeostasis (Boström et al 2012). Level of irisin plasma responds to continuous moderate-intensity exercise (CME) and high-intensity interval exercise (HIIE) exercises in women and men with normal BMI, obtained results of an increase in both types of exercise. However, a significant increase occurred in HIIE, where the increase of irisin levels up to $30 \%$ within \pm 5 minutes after exercise and lasts up to 1 hour after exercise as shown in Figure 3 (Huh et al 2014).

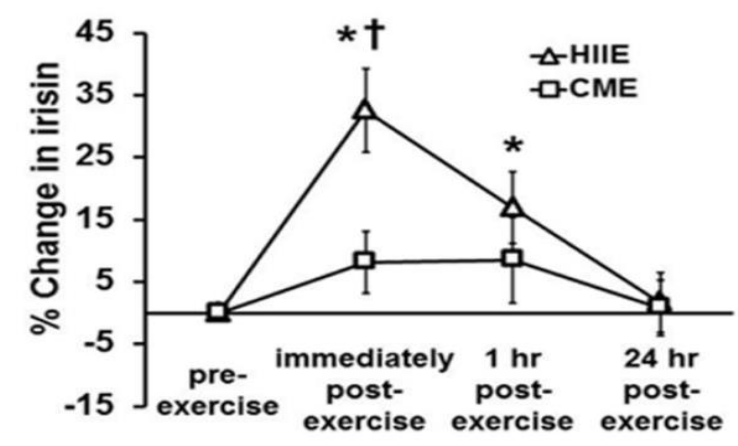

Figure 3. Maximum Irisin Concentration after HIIE and CME exercise.
Whereas, in another study mentioned that the time to increase irisin levels was different, where irisin response at a single exercise increased after 6 hours (18\%) and 19 hours $(23 \%)$ at HIIE, when compared to low intensity exercise (LIE) which decreased irisin response as shown in Figure 4 (Huh et al 2014, Tsuchiya et al 2014).

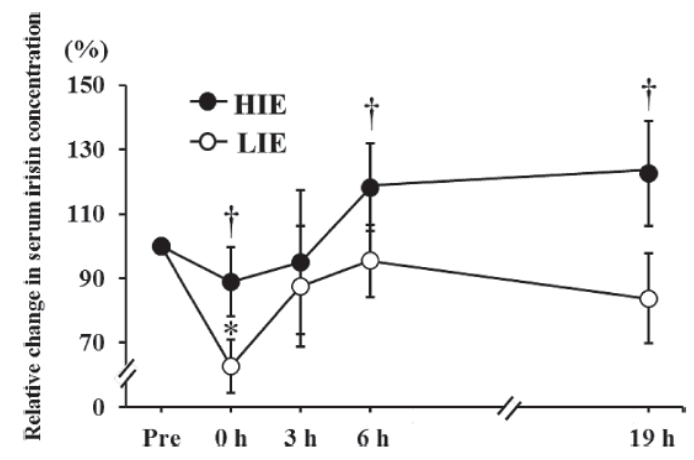

Fig. 4. Changes of Irisin Serum Concentration After HIE and LIE administered.

\section{CONCLUSION}

Exercise plays a role in increasing energy output through fat browning modulation of WAT to the nature of BAT. This increase in energy output is caused by an increase in thermogenesis of WAT. HIIE increases irisin secretion higher than other intensities hence it more effective when used for obesity intervention.

\section{REFERENCES}

Afshin A, Forouzanfar MH, Reitsma MB, et al (2017). Health effects of overweight and obesity in 195 countries over 25 years. The New England journal of medicine 377, 13-27

Astrand P, Rodahl K, Dahl H, S S (2003). Textbook of work physiology: Physiological bases of exercise. 4th Ed. 4. New York, Mc Graw-Hill Book

Bompa, Haff (2009). Periodization: Theory and methodology of training. 5th Ed. USA, Human Kinetics

Bompa (1994). Theory and methodology of training. 3rd Ed. Lowa, Kendall Hunt Publishing Company

Boström P, Wu J, Jedrychowski MP, et al (2012). A PGC1-alpha-dependent myokine that drives brownfat-like development of white fat and thermogenesis. Nature 481, 463-8

Cannon B, Nedergaard J (2004). Brown adipose tissue: function and physiological significance. Physiological reviews $84,277-359$ 
Cedikova M, Kripnerová M, Dvorakova J, et al (2016). Mitochondria in white, brown, and beige adipocytes. Stem Cell International, 1-11

Cui X-B, Chen S-Y (2017). White adipose tissue browning and obesity. Journal of Biomedical Research 31, 1-2

Emral (2017). Pengantar teori dan metodologi pelatihan fisik. Depok, Kencana

Foss, Keteyjan (1998). Fox's physiological basis for exercise and sport. 6th Ed. Philadelphia, WBC Brown and Benchmark

Fox E, Bower R, M F (1993). The physiological for exercise and sport. 5th Ed. Philadephia, WBC Brown and Benchmark

Fox SM, 3rd, Naughton JP, Haskell WL (1971). Physical activity and the prevention of coronary heart disease. Annals of clinical research 3, 404-32

Guyton, Hall (2014). Buku ajar fisiologi kedokteran. 12th Ed. Indonesia, Elsevier

Huh JY, Mougios V, Kabasakalis A, et al (2014). Exercise-induced irisin secretion is independent of age or fitness level and increased irisin may directly modulate muscle metabolism through AMPK activation. The Journal of clinical endocrinology and metabolism 99, E2154-61

Kent M (2014). The Oxford Dictionary sport science and medicine. 1st Ed. USA, Oxford University Press

Linda S (2014). ACSM's guidelines for exercise testing and prescription 9th Ed. Philadelphia, Lippincott Williams \& Wilkins

Lubis J (2013). Panduan praktis penyusunan program latihan. Jakarta, Raja Grafindo

Moreno-Navarrete JM, Ortega F, Serrano M, et al (2013). Irisin is expressed and produced by human muscle and adipose tissue in association with obesity and insulin resistance. The Journal of clinical endocrinology and metabolism 98, E769-78

Perakakis N, Triantafyllou GA, Fernandez-Real JM, et al (2017). Physiology and role of irisin in glucose homeostasis. Nature reviews Endocrinology 13, 32437

Rejeki P, Harjanto, Argarini, I S (2016). Comparison effect of CV 12, ST 36 and ST 40 EA on short term energy balance regulation in high fat diet rat. Folia Medica Indonesiana 52, 174-9

Rejeki P, Wiyasihati S, Atika (2017). Potency of Cv12 acupuncture as obesity prevention through modulation of $\mathrm{a}$ and $\mathrm{b}$ estrogen receptors expression on the adipose tissue of ovariectomized mice. Folia Medica Indonesiana 53, 24-8

Robert K (2009). Biokimia harper. Jakarta, EGC

Saely CH, Geiger K, Drexel H (2012). Brown versus white adipose tissue: A mini-review. Gerontology 58, $15-23$

Sanchez-Delgado G, Martinez-Tellez B, Olza J, Aguilera CM, Gil A, Ruiz JR (2015). Role of exercise in the activation of brown adipose tissue. Annals of nutrition \& metabolism 67, 21-32

Sudikno H, Meti D, H R (2015). Faktor risiko overweight dan obese pada orang dewasa di Indonesia (Analisis Data Riset Kesehatan Dasar 2013). Gizi Indonesia 38, 91-104

Sukadiyanto (2005). Pengantar teori dan metodologi melatih fisik. Yogyakarta, FIK UNY

Tsuchiya Y, Ando D, Goto K, Kiuchi M, Yamakita M, Koyama K (2014). High-intensity exercise causes greater irisin response compared with low-intensity exercise under similar energy consumption. The Tohoku journal of experimental medicine 233, 135-40 WHO (2016). Obesity and overweight. Accessed September 25th, 2017 